\title{
A long and winding road to the RNA world
}

\author{
ANITA H. CORBETT \\ Department of Biochemistry, Emory University School of Medicine, Atlanta, Georgia 30322, USA
}

Compared to many contributors, I am a relative late-comer to the RNA field, even an interloper if you will. However, my perception is that this field welcomes researchers who enter by way of relevant discoveries. In my burgeoning studies of RNA, I have benefited from the generosity of great scientists who have been willing to take time out of their busy schedules to contemplate my results and provide their insight. Such greats as Joan Steitz, Christine Guthrie, Bill Marzluff, and Jo Ann Wise (to name just a few) have become not only role models but also informal advisors and/or collaborators. Perhaps it greased my entry into the field to share a first name with Dr. Anita Hopper, one of the giants in the field of RNA biology, but I have found the RNA world to be more supportive and accepting than many of the other fields I have flirted with over the years. This attitude of support, acceptance, and intellectual generosity has always been reflected in the RNA journal, which publishes impactful work in the field of RNA biology with no nod to the politics that are pervasive at many other journals. For this reason, I have aspired to publish my own work in RNA from the early days of the journal. Admittedly I am a bit of a slow-starter because I finally achieved this goal in 2014 just in time to become part of the first 20 years of the journal.

My interest in RNA biology and awareness of the RNA journal arose while I was a post-doctoral fellow in Pamela Silver's laboratory in the mid-1990s. While my own research at the time examined mechanisms for protein import into the nucleus, many of my lab mates were focused on understanding the function of rather elusive RNA binding proteins. I was a bystander to the investigations that stemmed from interest in the Saccharomyces cerevisiae RNA binding protein, Npl3. I was fortunate at this time to publish my first paper in collaboration with Dr. Anita Hopper helping to clarify the function of one of the original rna mutants, rna1-1. However, I largely was relegated to living vicariously in the RNA world through participation in lab meetings, discussions with my lab mates, and comments I provided on manuscript drafts. I vividly recall when a lab mate's paper was accepted to $R N A$ thinking that was the pinnacle of achievement in the RNA world. Due to my growing fascination with the multi-faceted func-

Corresponding author: acorbe2@emory.edu

Article and publication date are at http://www.rnajournal.org/cgi/doi/ $10.1261 /$ rna.049841.115. Freely available online through the RNA Open Access option. tion of RNA binding proteins, I became determined to enter into the RNA world. With this determination came the goal of publishing my work in RNA. Somehow I would know I had officially arrived when I could count a publication in $R N A$ among my accomplishments.

As with much research that employs yeast genetics, my subsequent entry into the RNA world was facilitated by a screen. In the Silver laboratory, while screening for factors required for nuclear localization of $\mathrm{Npl} 3$, I identified a mutant of the RNA binding protein, Nab2. Nab2 was originally identified among the Nuclear poly $(\underline{A})$ binding $(\mathrm{Nab})$ proteins by Maury Swanson when he was characterizing S. cerevisiae hnRNP proteins in the Dreyfuss laboratory. Maury's efforts identified a large number of important RNA binding proteins, so he had a plethora of proteins to characterize. After an initial report, studies of NAB2 waned, likely because conditional alleles of this essential gene were surprisingly elusive to obtain. While in the Silver laboratory, I tried to interest many rotons and fellow post-doctoral fellows in the mutant allele that had inexplicably (to this day) emerged from my screen. Apparently my sales pitch was poor as no one was interested. Thus, when I established my own laboratory at Emory University, this nab2 mutant moved with the other $-80^{\circ} \mathrm{C}$ freezer stocks and took up residence in Atlanta.

For a number of years, this nab2 mutant remained in the freezer and seemed destined to stay there until a determined graduate student, Deanna Green, told me that she had chosen to rotate in my laboratory because of my passion in talking about RNA biology in a first year graduate course. She dug into the freezer and our studies of Nab2 began. Initial experiments were very standard as some rudimentary characterization of the protein was required. In my mind, these studies did not merit a submission to RNA but at least we were moving in the right direction. Our work proceeded, characterizing the role of Nab2 using yeast genetics and cell biology as well as structural biology approaches that were carried out in collaboration with another key scientific and life mentor, Dr. Murray Stewart.

In 2006, a critical grant review changed the direction of our research and paved the way for what would become our first $R N A$-worthy manuscript. While reviewers of the grant

(c) 2015 Corbett This article, published in RNA, is available under a Creative Commons License (Attribution-NonCommercial 4.0 International), as described at http://creativecommons.org/licenses/by-nc/4.0/. 
praised the mechanistic experiments proposed to decipher the function of $\mathrm{Nab} 2$, they expressed significant concern that the studies might not translate to human cells where no Nab2 ortholog had been described. This summary statement pushed us to draw on our recent structural studies to identify a putative human ortholog of Nab2, the aptly named zinc finger Cys3His \#14 (ZC3H14) protein. A talented long-term member of the lab, Sara Leung, characterized splice variants of human $\mathrm{ZC} 3 \mathrm{H} 14$ and localized the protein to nuclear speckles, work that was published in Gene as mechanistic insight required for a publication in $R N A$ was lacking. These studies sparked an interest in tissue-specific functions of this protein. While budding yeast is an optimal organism for mechanistic studies of conserved pathways, it is sub-optimal for the study of tissue-specific functions. Drawing on local expertise, we initiated a collaboration with Dr. Ken Moberg (Emory University, Department of Cell Biology) to study the Drosophila ZC3H14/Nab2 protein, which we termed $\mathrm{dNab} 2$, a rather mundane name for the fly community.

Studies of dNab2 carried out by a talented graduate student, ChangHui Pak, who was either brave or naïve enough to take on this project, quickly revealed that the gene is essential in flies as in yeast and hypomorphic mutants show pleiotropic phenotypes affecting a number of different tissues. We were literally scratching our heads trying to decide what tissue we should study, when a phone call came in that provided clear and exciting direction. Colleagues at the Max Planck Institute of Molecular Genetics in Berlin led by Andreas Kuss were studying inherited forms of intellectual disability (previously termed mental retardation). In two separate families, they had linked the occurrence of intellectual disability to mutation of $\mathrm{ZC} 3 \mathrm{H} 14$. This finding led us to focus on understanding the neuronal function of ZC3H14/dNab2. In a large collaborative effort, we reported the identification of the human disease and creation of the Drosophila model of the disease. However, in my mind, a burning question remained. Could we actually demonstrate that the human protein and fly protein carry out the same function? This important question was tackled by members of Ken Moberg's laboratory including a post-doctoral fellow, Seth Kelly. Using fly genetics, Seth demonstrated that transgenic expression of human $\mathrm{ZC} 3 \mathrm{H} 14$ specifically in neurons, could rescue many phenotypes of $d N a b 2$ zygotic mutant flies. His studies included functional assays such as locomotion as well as molecular assays examining poly(A) tail length. This work was very important as it not only validated the use of the fly model but also included the first evidence that human $\mathrm{ZC} 3 \mathrm{H} 14$ was critical for proper control of poly(A) tail length, a function previously only demonstrated in budding yeast and flies. This, I thought, might be my chance to publish important and relevant work in RNA.

We worked hard to put together a polished manuscript, pushed the button for the submission, and held our collective breath. We were delighted when reviews were returned with minor comments and the Editor stated that we could merely make the changes with no need for the manuscript to be returned to the reviewers. Finally, with the publication of Kelly and Pak et al. in 2014, I had arrived in the RNA world!

While publication in $R N A$ was a major achievement for me, this work highlights a major area of research for the future that is pervasive in the world of RNA biology. There are many examples where mutation of a gene encoding an RNA binding protein that is ubiquitously expressed, such as $\mathrm{ZC} 3 \mathrm{H} 14$, leads to tissue-specific disease. While many of these diseases impact neurological function, this is not always the case. A striking example is mutation of the nuclear poly(A) binding protein, PABPN1, which is a nuclear-localized polyadenosine RNA binding protein that shares many properties with ZC3H14. Mutation of PABPN1 leads to a specific form of muscular dystrophy, oculopharyngeal muscular dystrophy (OPMD). Thus, major challenges for the future include understanding the basic functions of key factors such as RNA binding proteins and then integrating this information into the context of specific tissues impacted in human disease. With these challenges ahead, there will be many exciting studies to pursue and publish as the RNA journal enters its next 20 years. 

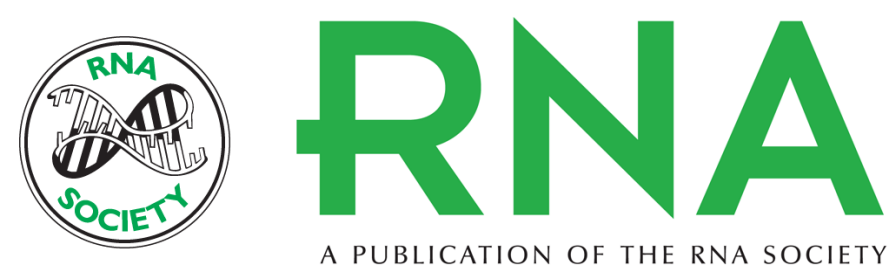

A PUBLICATION OF THE RNA SOCIETY

\section{A long and winding road to the RNA world}

Anita H. Corbett

RNA 2015 21: 590-591

Open Access Freely available online through the RNA Open Access option.

Creative This article, published in RNA, is available under a Creative Commons License Commons (Attribution-NonCommercial 4.0 International), as described at

License http://creativecommons.org/licenses/by-nc/4.0/.

Email Alerting Receive free email alerts when new articles cite this article - sign up in the box at the Service top right corner of the article or click here.

To subscribe to $R N A$ go to:

http://rnajournal.cshlp.org/subscriptions

(C) 2015 Corbett; Published by Cold Spring Harbor Laboratory Press for the RNA Society 